\title{
ANALISIS BEBAN KERJA KARYAWAN UNTUK MEMENUHI KEBUTUHAN PRODUKSI DI UKM RISSOLIA
}

\section{WORKLOAD ANALYSIS OF UKM RISSOLIA EMPLOYEES TO MEET PRODUCTION NEEDS}

\author{
Viesya Ananda Putri ${ }^{1}$, Nur Yulianti Hidayah ${ }^{2 *}$ \\ ${ }^{1,2}$ Program Studi Teknik Industri, Universitas Pancasila, Srengseng Sawah, Jagakarsa, Jakarta (12640) \\ *Email: nurhidayah@univpancasila.ac.id
}

\begin{abstract}
ABSTRAK
Dalam memenuhi kebutuhan konsumen tentunya akan bersinggungan dengan kebutuhan karyawan sebagai pelaksana kegiatan produksi. Perencanaan sumber daya manusia dibutuhkan dalam menentukan jumlah karyawan yang ideal pada suatu usaha. Ketersediaan karyawan harus sesuai dengan beban kerja dalam melakukan kegiatan proses produksi. Adapun jumlah karyawan akan mempengaruhi produktivitas usaha dalam mencapai target produksi. UKM Rissolia merupakan UKM yang bergerak di bidang kuliner yang menjual jajanan pasar dengan produknya risol mayo daging asap, risol rogut, pastel, arem-arem, sus, dan pie buah. Saat ini UKM Rissolia memiliki 3 karyawan. Permasalahan yang dihadapi saat ini adalah UKM ini belum dapat memenuhi kebutuhan konsumen dikarenakan keterbatasan jumlah karyawan yang dimiliki dan belum dapat menentukan jumlah produk yang harus dibuat setiap bulannya. Dari hasil perhitungan peramalan dengan metode Simple Average diperoleh peramalan pemintaan untuk 6 bulan ke depan yaitu April-September 2021 sebanyak 92.742 pcs atau 15.457 pcs per bulan dengan nilai kesalahan peramalan sebesar $29 \%$. Rata-rata geometriwaktu siklus adalah 3,104 menit per pcs dan rata-rata geometri waktu baku adalah 4,08 menit per pcs. Hasil analisis beban kerja dan kebutuhan tenaga kerja dengan menggunakan Workload Analysis dan Work Force Analysis, UKM Rissolia membutuhkan 5 orang karyawan sehingga perlu adanya penambahan 2 orang karyawan baru.
\end{abstract}

Kata Kunci: Peramalan Permintaan, Waktu Siklus, Waktu Baku, Workload Analysis, Work Force Analysis.

ABSTRACT

In order to meet customer needs, it will probably cross with the demands of employees as executors of industrial activities. In addition to determining the amount of employees for a company, human resource planning is required. Employee availability must correspond to the workload in carrying out production process operations. The amount of employees will have an impact on business productivity in terms of meeting production goals. UKM Rissolia is a culinary that sells market snacks such as smoked beef risol mayo, rogut risol, pastel, arem-arem, soes, and fruit pie. UKM Rissolia currently employs 3 people. The issue is that these UKM have been unable to meet consumer demands due to a lack of employees and their inability to identify the amount of products that must be produced each month. Forecasted demand for the next 6 months, namely April-September 2021, is 92,742pcs or 15,457 pcs/month, with a forecasting error of $29 \%$ based on the results of forecasting calculations using Simple Average methods. The average cycle time is 3,104 minutes/pcs, while the average standard time is 4.08 minutes/pcs. According to the findings of the analysis, UKM Rissolia requires to hire of two new employees, as determined by the methods of Workload Analysis and Work Force Analysis.

Keywords: Forecasting, Cylce Time, Standard Time, Workload Analysis, Work Force Analysis.

\section{Pendahuluan}

Dunia industri di Indonesia saat ini sudah semakin berkembang pesat. Salah satunya ditunjukkan dengan banyakan UKM (Usaha Kecil dan Menegah) yang hadir dikalangan 
masyarakat. Berdirinya UKM ini juga mendapatkan dukungan positif dari pemerintah dengan tujuan untuk menumbuhkan dan mengembangkan perekonomian nasional.

Tentu adanya persaingan pada setiap UKM menuntut untuk terus meningkatkan kinerjanya dengan cara dapat memenuhi kebutuhan konsumen sebaik mungkin. Kaitannya dengan memenuhi kebutuhan konsumen akan bersinggungan dengan kegiatan produksi yang melibatkan sumber daya manusia sebagai pelaksana kegiatan produksi. oleh sebab itu karyawan merupakan suatu faktor penting yang harus dipehatikan dalam kegiatan suatu usaha.

Perencanaan sumber daya manusia ini sangat diperlukan akan terjadinya kesinambungan antara beban kerja dengan jumlah karyawan yang dimiliki. Perencanaan sumber daya manusia dapat dilakukan dengan efektif dan efiesien jika perencananya dapat mengetahui apa dan bagaimana sumber daya manusia itu sendiri (Priyono, 2008).

Ketersediaan karyawan akan mempengaruhi produktifitas suatu kegiatan usaha. Dimana jika karyawan yang dimiliki kurang akan mengakibatkan suatu usaha tidak mampu memenuhi kebutuhan konsumen. Kelebihan karyawan akan mengakibatkan pengeluaran biaya yang seharusnya tidak diperlukan.

UKM Rissolia merupakan suatu kegiatan usaha yang bergerak dibidang kuliner atau jajanan pasar yang berdiri sejak 2015. UKM Rissolia saat ini menjual berbagai macam jajanan pasar yang terbagi atas dua kategori yaitu menu utama dan menu titipan. Menu utama ini diproduksi secara langsung yang terdiri atas yaitu risol mayo daging asap, risol rogut ayam, pastel, arem-arem, soes, dan pie buah. Sedangkan menu titipan merupakan kue yang dijual tidak diproduksi secara langsung.

Permasalahan yang sering dihadapi oleh UKM Rissolia kesulitan dalam memenuhi kebutuhan konsumen selain itu juga sulit untuk menentukan jumlah produksi yang harus dicapai setiap bulannya. Hal ini terjadi tentuya karena penjualan setiap bulannya yang berbedabeda. Adapun data penjualan menu utama pada UKM Rissolia ditunjukkan pada Tabel 1.

Tabel 1. Jumlah Penjualan Menu Utama di UKM Rissolia Bulan Okt 2020-Maret 2021

\begin{tabular}{clc}
\hline No & \multicolumn{1}{c}{ Periode } & Penjualan \\
\hline 1 & Oktober 20 & 14.944 \\
2 & November 20 & 18.287 \\
3 & Desember 20 & 20.001 \\
4 & Januari 21 & 10.639 \\
5 & Februari 21 & 12.767 \\
6 & Maret 21 & 16.100 \\
\hline Sumber : UKM Rissolia
\end{tabular}

Pada peneliatian ini menggunakan data penjulan menu utama UKM Rissolia dari periode bulan Oktober 2020 - Maret 2021. Berdasarkan Tabel 1.1 penjualan mengalami peningkatan sebesar 13,43\% sedangkan penjualan mengalami penurunan yang signifikan pada bulan Januari akibat dari kondisi pandemi COVID-19. Namun seiring dengan berjalannya new normal life penjualan kembali meningkat pada bulan Februari 2021- Maret 2021 sebesar $18,68 \%$.

Saat ini UKM Rissolia memiliki karyawan sebanyak 3 karyawan. Berdasarkan informasi yang didapatkan dari hasil wawancara oleh pemilik usaha dalam 1 hari terkadang UKM Rissolia ini dapat menolak pesanan sebanyak kurang lebih 50 pcs karena ketidakmampuan dalam memenuhi pemintaan yang akan datang. Tentunya lonjakan penjualan yang terjadi memberikan dampak terhadap waktu kerja para karyawan yang menyebabkan sering terjadinya lembur. Hal tersebut tejadi karena jumlah waktu yang tersedia sangat erat hubungannya dengan jumlah karyawan yang dimiliki UKM Rissolia saat ini yang hanya berjumlah 3 orang. 
Permasalahan tersebut mendorong penulis untuk memberikan solusi pada UKM Rissolia yaitu berupa analisis beban kerja karyawan agar dapat memenuhi kebutuhan produksi dengan metode Analisis Beban Kerja (Work Load Analysis) dan Analisis Kebutuhan Tenaga Kerja (Work Force Analysis).

\section{Metodologi Penelitian}

Dalam penelitian ini obyek penelitian adalah beban kerja. Pengambilan data dilakukan dengan beberapa teknik sebagai berikut :

1. Observasi

Dilakukan dengan melakukan survey secara langsung ke UKM Rissolia. Data-data yang diperlukan sebagai berikut :

a. Data historis penjualan selama bulan Oktober 2020 - Maret 2021.

b. Durasi atau waktu yang dibutuhkan untuk memproduksi suatu varian produk.

c. Data jumlah tenaga kerja pada bagian produksi.

d. Data waktu kerja yang tersedia per hari

2. Wawancara

Dilakukan dengan melakukan sesi tanya jawab dengan pihak yang kompeten yaitu pemilik usaha.

3. Dokumentasi

Dokumentasi ini dilakukan sebagai pelengkap dari penelitian ini. Dokumentasi ini dapat berupa foto ataupun dokumen sebagai penunjang dari penelitian yang dilakukan.

Setelah data penjualan didapatkan maka hal yang dilakukan adalah peramalan permintaan untuk 6 bulan yang akan datang. Dilakukannya peramalan untuk mengetahui pemintaan yang akan datang. Titik awal dari setiap perencanaan adalah data aktual permintaan pelanggan atau yang diharapkan. waktu yang Oleh karenanya produksi harus dimulai dari permintaan yang diharapkan dengan cara melakukan peramalan permintaan pelanggan atau yang diharapkan (Chapman, 2006).

Pada penelitian ini peramalan menggunakan metode Simple Average. Simple Average adalah rata-rata permintaan yang terjadi seluruh periode dibagi dengan jumlah seluruh periode atau menggunakan sejumlah data aktual dari periode-periode sebelumnya yang kemudian dihitung rata-ratanya untuk meramalkan periode waktu berikutnya (Haryono, 2015), oleh sebab itu penelitian ini menggunakan metode tersebut sebab berdasarkan hasil perkiraan permintaan, maka akan dapat ditentukan perkiraan beban kerja dan jumlah karyawan yang dibutuhkan selama periode analisis, dimana UKM ini tidak menghendaki adanya perubahan jumlah tenaga kerja yang fluktuatif (turn over) sehingga jumlah tenaga kerja di sepanjang periode analisis akan sama. Dengan demikian penggunaan metode peramalan Simple Average dianggap tepat karena akan menghasilkan jumlah produksi yang sama, beban kerja yang sama dan jumlah tenaga kerja yang sama di setiap bulannya. Adapun persamaan yang dipergunakaan sebagai berikut (Haryono, 2015) :

Dimana:

$$
\mathrm{Fi}+1=\sum \mathrm{At} / \mathrm{N}
$$

$\mathrm{Fi}+1$ : peramalan untuk periode ke $\mathrm{i}+1$

At : nilai aktual tahun $\mathrm{ke}-1$

$\mathrm{N}$ : banyaknya data

Setelah ditentukannya permalan maka langkah selanjutnya adalah pengukuran kesalahan terhadap peramalan dengan menggunakan perhitungan MAPE (Mean Absolute Percentage Error). Mean Absolute Percentage Error merupakan ukuran kesalahan relative yang akan mengahasil output presentase. Adapun persamaan yang dipergunakkan sebagai berikut (Montgomery dkk., 2015):

Dimana :

$$
\text { MAPE }=(100 / \mathrm{N}) \times|((\mathrm{At}-\mathrm{Ft}) / \mathrm{At})|
$$


Jurnal SEOI - Fakultas Teknik Universitas Sahid Jakarta

Vol 3 edisi 2 tahun 2021

At : data aktual

Ft : data peramalan

$\mathrm{N}$ : banyaknya data

Pengukuran waktu kerja (Time Study) pada dasarnya merupakan suatu usaha untuk menentukan lamanya waktu kerja yang diperlukan oleh seorang operator untuk menyelesaikan suatu pekerjaan. (Rinawati, 2012). Hal pertama yang dilakukan yaitu menentukan waktu siklus atau cycle time dari enam varian produk yang di uji. Waktu siklus merupakan waktu yang dibutuhkan untuk membuat satu unit produk pada satu stasiun kerja (Purnomo, 2003). Adapun persamaan yang dipergunakkan sebagai berikut :

$$
\mathrm{Ws}=\frac{\Sigma \mathrm{X}_{1}}{\mathrm{~N}}
$$

Dimana:

$\Sigma \mathrm{X}_{1}$ : Harga rata-rata sub grup ke i

$\mathrm{N}$ :Jumlah pengamatan yang dilakukan

Langkah berikutnya menentukan waktu normal untuk setiap enam varian produk. Waktu normal adalah suatu elemen operasi kerja yang menunjukkan bahwa seorang tenaga kerja berkualifikasi baik akan bekerja dalam menyelesaikan pekerjaan pada waktu kerja yang normal (Wignjosoebroto, 2000). Pada penentuan waktu normal ini dibutuhkan faktor penyesuaian yang dimana dipillh dengan menggunakan metode obyektif. Adapun metode yang digunakan menggunakan metode obyektif besarnya harga faktor penyesuaian (p) memiliki tiga batasan, yaitu (Anggawisastra \& Sutalaksana, 2006) :

1. $\mathrm{p}>1$ bila pengukur berpendapat bahwa operator bekerja di atas normal (terlalu cepat)

2. $\mathrm{p}<1$ bila pengukur berpendapat bahwa operator bekerja di bawah normal (terlalu lambat)

3. $\mathrm{p}=1$ bila pengukur berpendapat bahwa operator bekerja dengan wajar

Persamaan yang digunakan pada waktu normal sebagai berikut:

$$
\mathrm{Wn}=\mathrm{Ws} \times \mathrm{P}
$$

Dimana:

Ws : Waktu Siklus

$\mathrm{P} \quad$ : Faktor Penyesuaian

Langkah akhir dalam pengukuran waktu kerja pada penilitian ini yaitu menentukan waktu baku setiap varian produk. Dalam penentuan waktu baku untuk menentukan target produksi dilakukan dengan cara pengukuran yang dilakukan secara langsung dan menggunakan jam henti. Pada waktu baku juga adanya faktor kelonggaran (allowance) yang mana hal tersebut dapat terjadi dari internal maupun eksternal. Adapun persamaan yang digunakan dalam menentukan waktu baku sebagai berikut (Wignjosoebroto, 2000):

$$
\begin{aligned}
\text { Waktu Baku } & =\mathrm{Wn}+(\mathrm{Wn} \times \% \text { Allowance }) \\
\text { Waktu Baku } & =\mathrm{Wn}+\frac{100 \%}{100 \%-\% \text { Allowance }}
\end{aligned}
$$

Setelah waktu baku dan peramalan permintaan telah didapatkan maka dapat menentukan jumlah tenaga kerja yang ideal. Pada penelitian ini dilakukan dengan metode Workload Analysis yang dimana dapat diartikan sebagai suatu proses untuk menghitung beban kerja pada suatu posisi/sub-posisi dan juga kebutuhan jumlah orang untuk mengisi posisi/sub posisi tersebut (Widodo dkk., 2020). Adapun persamaan yang dipergunakan sebagai berikut :

$$
\text { WLA }=\frac{\text { Jumlah Produk } \times \text { Waktu Standar Tiap Unit }}{\text { Jam Kerja } \times \text { Hari Kerja/Bulan }} \times 1 \text { orang }
$$

Selanjutnya menentukan jumlah tenaga kerja dengan menggunakan metode Work Force Analysis. Pada metode ini memperhatikan tingkat absensi dan perputaran tenaga kerja pada suatu usaha. Metode Work Force Analysis didefinisikan sebagai melakukan analisis terhadap kemampuan operator sekarang untuk memenuhi jumlah karyawan (Martoyo, 2000). Adapun persamaan yang dipergunakan sebagai berikut:

$$
\mathrm{WFA}=\mathrm{WLA}+\% \text { Absensi } \% \text { LTO }
$$




\section{Tingkat Absensi}

Tingkat absensi adalah perbandingan antara hari-hari yang hilang dengan keseluruhan hari yang tersedia untuk bekerja. Adapun persamaan yang digunakan untuk mengukur tingkat absensi karyawan sebagai berikut (Martoyo, 2000):

$$
\text { Tingkat Absensi }=\frac{\text { Hari Kerja yang Hilang }}{\text { Hari Kerja yang Ada }} \times 100 \%
$$

\section{Perputaran Tenaga Kerja (Labour Turn over)}

Perputaran tenaga kerja merupakan masuk dan keluarnya tenaga kerja dari suatu perusahaan. adapun persamaan yang digunakan dalam menentukan perputangan tenaga kerja atau labour turn over sebagai berikut (Martoyo, 2000):

$$
\mathrm{LTO}=\frac{\text { Tenaga Kerja Masuk }+ \text { Tenaga Kerja Keluar }}{\text { Jumlah Tenaga Kerja }} \times 100 \%
$$

\section{Hasil dan Pembahasan}

\subsection{Peramalan}

Peramalan dilakukan untuk mengetahui perkiraan permintaan yang akan datang yaitu untuk bulan April- September 2021. Data yang digunakan untuk membuat peramalan adalah data penjualan menu utama UKM Rissolia selama bulan Oktober2020-Maret 2021 seperti yang ditampilkan pada Gambar 1.

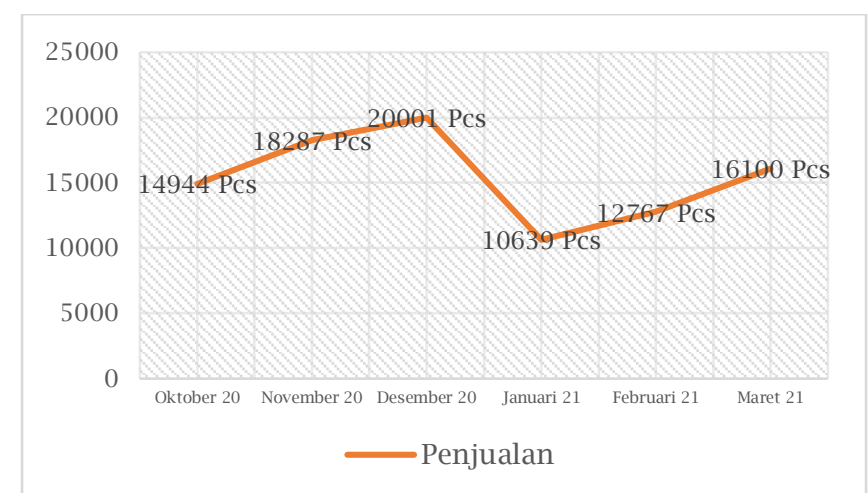

$$
\begin{gathered}
\text { Gambar 1. Data Penjualan Menu Utama UKM Rissolia } \\
\text { Sumber : UKM Rissolia }
\end{gathered}
$$

Penelitian ini menggunakan metode Simple Average untuk meramalkan permintaaan 6 bulan yang akan datang. Adapun hasil permalan ditunjukkan pada Tabel 2.

Tabel 2. Peramalan Permintaan dengan Metode Simple Average

\begin{tabular}{clc}
\hline No & \multicolumn{1}{c}{ Bulan } & Peramalan $(p c s)$ \\
\hline 1 & April 21 & 15.457 \\
2 & Mei 21 & 15.457 \\
3 & Juni 21 & 15.457 \\
4 & Juli 21 & 15.457 \\
5 & Agustus 21 & 15.457 \\
6 & September 21 & 15.457 \\
& Total & 92.742 \\
\hline
\end{tabular}

Salah satu perhitungan peramalan dengan menggunakan metode peramalan Simple Average pada bulan April 2021 sebagai berikut:

$$
\begin{aligned}
& \mathrm{Fi}+1=\sum_{14.944+18.287+20.001+10.639+12.767+16.100} \\
& \mathrm{~F}_{6+1}=\frac{1 \mathrm{~N}}{6}
\end{aligned}
$$


Jurnal SEOI - Fakultas Teknik Universitas Sahid Jakarta

Vol 3 edisi 2 tahun 2021

$\mathrm{F}_{7}=\frac{92.738}{6}$

$\mathrm{F}_{7}=15.456 .333 \approx 15.457$

Setelah mendapatkan hasil peramalan maka perlu dilakukan pengukuran kesalahan peramalan dengan menggunakan MAPE (Mean Absolute Percentage Error). Adapun hasil pengukuran tersebut disajikan pada Tabel 3.

Tabel 3. Tabel Perhitungan Nilai MAPE (Mean Absolute Percentage Error)

\begin{tabular}{clccc} 
No & Periode & Aktual (At) & Permalan(Ft) & $\mid$ (At-Ft)/At $\mid$ \\
\hline 1 & Oktober 20 & 14.944 & - & - \\
2 & November 20 & 18.287 & 14.944 & 0,183 \\
3 & Desember 20 & 20.001 & $16.615,5$ & 0,169 \\
4 & Januari 21 & 10.639 & 17.744 & 0,668 \\
5 & Februari 21 & 12.767 & $15.967,75$ & 0,251 \\
6 & Maret 21 & 16.100 & $15.327,6$ & 0,048 \\
& & Total & 1,458 \\
& MAPE & & $29 \%$ \\
\hline
\end{tabular}

Dalam melakukan pengukuran kesalahan pada peramalan Simple Average, menggunakan persamaan sebagai berikut :

MAPE $=(100 / \mathrm{N}) \times|((\mathrm{At}-\mathrm{Ft}) / \mathrm{At})|$

MAPE $=\left(\frac{100}{5}\right) \times\left[\begin{array}{c}\left(\frac{18287-14944}{18287}\right)+\left(\frac{20001-16615,5}{20001}\right)+\left(\frac{10639-17744}{10639}\right)+\left(\frac{12767-15967.75}{12767}\right) \\ +\left(\frac{16100-15327.6}{16100}\right)\end{array}\right]$

MAPE $=\left(\frac{100}{5}\right) \times 1,458$

$\mathrm{MAPE}=29 \%$

Dalam hal ini menunjukan bahwa dengan menggunakan metode Simple Average kemungkinan terdapat kesalahan peramalan permintaan sebesar $29 \%$ terhadap permintaan aktual pada periode yang akan datang.

\subsection{Waktu Kerja}

Waktu kerja pada penelitian ini dilakukan dengan melakukan pengamatan pada proses kegiatan produksi untuk setiap varian produk. Dalam proses produksi menu utama ini dimulai dari tahap pencucian bahan-bahan hingga menjadi satu varian produk. Adapun durasi waktu setiap produk disajikan pada Tabel 4.

Tabel 4. Durasi Waktu Kegiatan Produksi Menu Utama UKM Rissolia

\begin{tabular}{clcc}
\hline No & Jenis Varian & $\begin{array}{c}\text { Durasi } \\
(\text { Menit })\end{array}$ & $\begin{array}{c}\text { Jumlah } \\
\text { Produk }(P c s)\end{array}$ \\
\hline 1 & Risol rogut Ayam & 341 & 150 \\
2 & Risol Mayo Asap & 237 & 125 \\
3 & Pastel & 226 & 60 \\
4 & Arem-arem & 265 & 50 \\
5 & Soes & 189 & 60 \\
6 & Pie Buah & 132 & 40 \\
\hline \multicolumn{2}{l}{ Sumber : UKM Rissolia 2021 }
\end{tabular}

a. Waktu Siklus

Dari hasil pengamatan yang telah dilakukan maka dilakukan perhitungan waktu siklus terhadap setiap varian produk. Adapun waktu siklus menu utama pada UKM Rissolia disajikan pada Tabel 5. 
Tabel 5. Waktu Siklus Per-Varian Produk Menu Utama UKM Rissolia

\begin{tabular}{clccc}
\hline No. & \multicolumn{1}{c}{ Jenis Produk } & $\begin{array}{c}\text { Waktu Proses Pembuatan } \\
\text { Produk (Menit) }\end{array}$ & $\begin{array}{c}\text { Produk yang dihasilan } \\
\text { (Pcs) }\end{array}$ & $\begin{array}{c}\text { Waktu Siklus } \\
\text { (menit) }\end{array}$ \\
\hline 1 & Risol Rogut Ayam & 341 & 150 & 2,273 \\
2 & Risol Mayo Daging Asap & 237 & 125 & 1,896 \\
3 & Pastel & 226 & 60 & 3,767 \\
4 & Arem-arem & 265 & 50 & 5,300 \\
5 & Kue Soes & 189 & 60 & 3,150 \\
6 & Pie Buah & 132 & 40 & 3,300 \\
& & Rata-Rata & & 3,104 \\
\hline
\end{tabular}

Menentukan waktu siklus risol rogut ayam dapat dilakukan dengan menggunakan persamaan sebagai berikut:

$\mathrm{Ws}=\frac{\sum \text { Waktu proses produksi }}{\mathrm{N}}$

Ws $=\frac{341}{150}$

$\mathrm{Ws}=2,273 \mathrm{menit} / \mathrm{pcs}$

Maka dalam penelitian ini rata-rata geometrik waktu siklus pada menu utama UKM Rissolia adalah 3,104 menit/pcs dengan menggunakan persamaan berikut:

Rata-rata Ws $=\sqrt[6]{2,273 \times 1,896 \times 3,767 \times 5,300 \times 3,150 \times 3,300}$

Rata-rata Ws $=3,104 \mathrm{menit} / \mathrm{pcs}$

\section{b. Waktu Normal}

Setelah menentukan waktu siklus, maka hal selanjutnya dilakukan adalah menentukan waktu normal. Sebelum melakukan perhitungan waktu normal dibutuhkan penyesuaian, dimana metode penyesuain yang dipilih adalah metode obyektif. Metode obyektif ini dasarkan dengan hasil pengamatan kegiatan proses operasi produksi pada UK Rissolia. Adapun besarnya penyesuaian dengan metode obyektif ditunjukkan sebagai berikut:

Tabel 6. Faktor Penyesuaian dengan Metode Obyektif

\begin{tabular}{|c|c|c|c|c|}
\hline No & & Keadaan & Lambang & Penyesuaian \\
\hline 1 & $\begin{array}{l}\text { Anggota badan yang } \\
\text { terpakai }\end{array}$ & Lengan atas, lengan bawah dan seterusnya & $\mathrm{D}$ & $5 \%$ \\
\hline 2 & Pedal kaki & Tanpa pedal kaki & $\mathrm{F}$ & $0 \%$ \\
\hline 3 & Penggunaan tangan & Keadaan tangan saling bantu atau bergantian & $\mathrm{H}$ & $0 \%$ \\
\hline 4 & $\begin{array}{l}\text { Koordinasi mata dengan } \\
\text { tangan }\end{array}$ & Sangat sedikit & I & $0 \%$ \\
\hline 5 & Peralatan & Perlu penekanan dan kontrol & $\mathrm{P}$ & $2 \%$ \\
\hline 6 & Berat beban & $0,45 \mathrm{~kg} \quad$ Total & B-1 & $\begin{array}{c}3 \% \\
10 \% \\
\end{array}$ \\
\hline
\end{tabular}

Sumber : UKM Rissolia

Berdasarkan dengan Tabel 6, maka faktor penyesuaian $\left(\mathrm{p}_{2}\right)$ adalah sebesar 10\% atau 0,10. Dengan asumsi kecepatan kerja adalah normal maka $\mathrm{p}_{1}=1$, untuk itu dapat diketahui faktor penyesuaian secara keseluruhan dapat dihitung dengan menjumlahkan $\mathrm{p}_{1}$ dan $\mathrm{p}_{2}$ sehingga memiliki nilai sebesar 1,10 . Selanjutnya saat faktor penyesuaian telah ditentukan maka waktu normal dapat diperhitungkan. Adapun waktu normal untuk setiap varian produk ditunjukkan pada Tabel 7.

Tabel 7. Waktu Normal Per-Varian Produk Menu Utama UKM Rissolia

\begin{tabular}{clccc}
\hline No & Jenis Produk & Waktu Siklus(Menit) & Faktor Penyesuaian & Waktu Normal(Menit) \\
\hline 1 & Risol Rogut Ayam & 2,273 & 1,1 & 2,501 \\
2 & Risol Mayo Daging & 1,896 & 1,1 & 2,086 \\
& Asap & 3,767 & 1,1 & 4,143 \\
3 & Pastel & 5,300 & 1,1 & 5,830
\end{tabular}


Jurnal SEOI - Fakultas Teknik Universitas Sahid Jakarta

Vol 3 edisi 2 tahun 2021

\begin{tabular}{lllll}
5 & Kue Soes & 3,150 & 1,1 & 3,465 \\
6 & Pie Buah & 3,300 & 1,1 & 3,630 \\
& & Rata-rata & & 3,414 \\
\hline
\end{tabular}

Dalam menentukan nilai siklus untuk risol rogut ayam dalam dilakukan dengan menggunakan persamaan berikut:

$\mathrm{Wn}=\mathrm{Ws} \times \mathrm{P}$

$\mathrm{Wn}=2,273 \times 1,1$

$\mathrm{Wn}=2,501 \mathrm{menit} / \mathrm{pcs}$

Maka pada waktu normal memiliki nilai rata-rata untuk menu utama UKM Rissolia adalah 3,424 menit/pcs dengan menggunakan persamaan berikut:

Rata-rata $\mathrm{Wn}=\sqrt[6]{2,501 \times 2,086 \times 4,143 \times 5,830 \times 3,465 \times 3,630}$

Rata-rata Wn $=3,414$ menit/pcs

c. Waktu Baku

Langkah akhir yaitu menentukan waktu baku dari setiap varian produk. Sebelum dapat menentukan waktu baku maka diperlukan penentuan faktor kelonggaran (allowance). Faktor kelonggaran ini didapatkan berdasarkan dengan hasil pengamatan pada tempat kerja kegiatan produksi. Adapun besarnya faktor kelonggaran yang ditentukan ditunjukkan pada Tabel 8 .

Tabel 8. Faktor Kelonggaran (Allowance)

\begin{tabular}{cllc}
\hline No & \multicolumn{1}{c}{ Faktor } & \multicolumn{1}{c}{ Keterangan } & Kelonggaran (\%) \\
\hline 1 & Tenaga kerja yang dikeluarkan & Ringan & 7,5 \\
2 & Sikap kerja & Duduk & 0 \\
3 & Gerakan kerja & Normal & 0 \\
4 & Kelelahan mata & Pandangan terus-menerus dengan fokus tetap & 7,5 \\
5 & Keadaan suhu tempat kerja & Normal & 0 \\
6 & Keadaan atmosfer & Cukup & 1 \\
7 & Keadaan lingkungan yang baik & Siklus kerja berulang-ulang antara 5-10 detik & 1 \\
8 & Kelonggaran kebutuhan pribadi & Wanita & 2,5 \\
& & Total & 19,5 \\
\hline
\end{tabular}

Sumber : UKM Rissolia

Setelah ditentukan faktor penyesuain, maka dapat ditentukan pula waktu baku untuk setiap varian produk. Adapun waktu baku setiap varian produk ditunjukkan pada Tabel 9.

Tabel 9. Waktu Baku Per-Varian Produk Menu Utama UKM Rissolia

\begin{tabular}{clccc}
\hline \multirow{2}{*}{ No } & \multicolumn{1}{c}{ Jenis Produk } & Waktu Normal (Menit) & Kelonggaran (\%) & Waktu Baku (Menit) \\
\hline 1 & Risol Rogut Ayam & 2,501 & 0,195 & 2,988 \\
2 & Risol Mayo Daging Asap & 2,086 & 0,195 & 2,492 \\
3 & Pastel & 4,143 & 0,195 & 4,951 \\
4 & Arem-arem & 5,830 & 0,195 & 6,967 \\
5 & Kue Soes & 3,465 & 0,195 & 4,141 \\
6 & Pie Buah & 3,630 & 0,195 & 4,338 \\
& & Rata-rata & & 4,080 \\
\hline
\end{tabular}

Dalam menentukan waktu baku risol rogut ayam dapat dilakukan dengan menggunakkan persamaan sebagai berikut:

$\mathrm{Wb}=\mathrm{Wn}+(\mathrm{Wn} \times \%$ Allowance $)$

$\mathrm{Wb}=2,501+(2,501 \times 0,195)$

$\mathrm{Wb}=2,988$ menit

Maka pada waktu baku memiliki nilai rata-rata geometric untuk menu utama UKM Rissolia adalah 4,080 menit/pcs dengan menggunakan persamaan berikut :

Rata-rata $\mathrm{Wb}=\sqrt[6]{2,988 \times 2,492 \times 4,951 \times 6,967 \times 4,141 \times 4,338}$

Rata-rata $\mathrm{Wb}=4,080$ menit/pcs

\subsection{Beban Kerja}


Langkah akhir pada penelitian ini adalah analisis beban kerja. Dalam melakukan analisis beban kerja pada penelitian ini menggunakan 2 metode yaitu Analisis Beban Kerja (Work Load Analysis) dan Analisis Kebutuhan Tenaga Kerja (Work Force Analysis).

UKM Rissolia saat ini memperkerjakan sebanyak 4 karyawan. Pada penelitan ini dilakukan analisis kebutuhan tenaga kerja hanya untuk divisi produksi. Pembagian kerja pada UKM Rissolia ditunjukkan pada Tabel 10.

\begin{tabular}{ccc} 
Tabel & 10. Data Karyawan UKM Rissolia \\
\hline No & Divisi & Jumlah Karyawan \\
\hline 1 & Pelayan Toko & 1 \\
2 & Produksi & 3 \\
& Total & 4 \\
\hline Sumber : UKM Rissolia
\end{tabular}

a. Analisis Beban Kerja (Work Load Analysis)

Analisis beban kerja dapat dilakukan ketika telah ditentukannya waktu baku proses produksi, mengetahui jumlah pemintaan yang diinginkan, hari kerja yang tersedia dan waktu kerja yang tersedia. Waktu baku yang digunakan merupakan rata-rata dari keseluruhan waktu baku proses produksi pada UKM Rissolia yang ditunjukkan pada Tabel 3.8 yaitu 4,313 menit. Sedangkan untuk permintaan yang digunakan merupakan jumlah dari hasil rata-rata peramalan 6 bulan ke depan seperti yang ditunjukkan pada tabel 3.1 yaitu 15.457 pcs. Hari kerja dan waktu kerja yang tersedia sesuai dengan hari kerja efektif pada UKM Rissolia ditunjukkan pada Tabel 11.

Tabel 11. Hari Kerja dan Waktu Kerja UKM Rissolia Periode April - September 2021

\begin{tabular}{cccc}
\hline No & Bulan & Hari Kerja efektif (Hari) & Waktu Kerja (Menit) \\
\hline 1 & April 21 & 26 & 12.480 \\
2 & Mei 21 & 21 & 10.080 \\
3 & Juni 21 & 26 & 12.480 \\
4 & Juli 21 & 26 & 12.480 \\
5 & Agustus 21 & 26 & 12.480 \\
6 & September 21 & 26 & 12.480 \\
& Total & 151 & 72.480 \\
\hline Sumber : UKM Rissolia
\end{tabular}

UKM Rissolia memiliki 6 hari kerja yaitu Selasa sampai dengan Minggu. Hari Senin UKM Rissolia libur baik untuk divisi produksi maupun divisi pelayan toko. Adapun uraian jadwal kerja sehari-hari sebagai berikut :

$\begin{array}{llll}\text { Selasa - Minggu } & & \text { Jum'at } & \\ 07.00-12.00: & \text { Bekerja } & 07.00-11.30: & \text { Bekerja } \\ 12.00-13.00: & \text { Istirahat } & 11.30-13.00: & \text { Istirahat } \\ 12.00-13.00: & \text { Bekerja } & 13.00-16.00: & \text { Bekerja }\end{array}$

Berdasarkan waktu kerja di UKM Rissolia, karyawan memiliki waktu kerja sebanyak 9 jam dalam satu hari. Waktu kerja terbagi atas 2 klasifikasi, dimana waktu efektif bekerja adalah 8 jam dan waktu istirahat adalah 1 jam. Waktu kerja efektif di UKM Rissolia ini nantinya akan dipergunakan untuk menghitung beban kerja dengan jumlah karyawan yang ada.

Berikut merupakan hasil perhitungan dengan menggunakan metode analisis beban kerja untuk enam bulan kedepan jumlah karyawan yang dibutuhkan pada Tabel 12.

Tabel 12. Analisis Beban Kerja (Work Load Analysis)

\begin{tabular}{clccccc}
\hline No & \multicolumn{1}{c}{ Bulan } & $\begin{array}{c}\text { Hari keja efektif } \\
\text { (Hari) }\end{array}$ & $\begin{array}{c}\text { Waktu Kerja } \\
\text { (Menit) }\end{array}$ & $\begin{array}{c}\text { Peramalan } \\
(\text { Pcs })\end{array}$ & $\begin{array}{c}\text { Waktu Baku } \\
\text { (Menit) }\end{array}$ & $\begin{array}{c}\text { WLA } \\
(\text { Orang) }\end{array}$ \\
\hline 1 & April 21 & 26 & 480 & 15.457 & 4.08 & 5,053 \\
2 & Mei 21 & 21 & 480 & 15.457 & 4.08 & 6,256 \\
3 & Juni 21 & 26 & 480 & 15.457 & 4.08 & 5,053 \\
4 & Juli 21 & 26 & 480 & 15.457 & 4.08 & 5,053 \\
5 & Agustus 21 & 26 & 480 & 15.457 & 4.08 & 5,053
\end{tabular}


Jurnal SEOI - Fakultas Teknik Universitas Sahid Jakarta

Vol 3 edisi 2 tahun 2021

\begin{tabular}{|c|c|c|c|c|c|}
\hline September 21 & 26 & 480 & $15.45^{\circ}$ & 4.08 & $\begin{array}{l}5,053 \\
5,236\end{array}$ \\
\hline
\end{tabular}

Persamaan yang dipergunakan untuk menentukan jumlah karyawan yang dibutuhkan pada bulan April 2021 sebagai berikut:

WLA $=\frac{\text { Jumlah Produk } \mathrm{x} \text { Waktu Standar Tiap Unit }}{\text { Jam Kerja } \mathrm{x} \text { Hari Kerja/Bulan }} \times 1$ orang

$\mathrm{WLA}=\frac{15.457 \times 4,080}{480 \times 26} \times 1$ orang

$\mathrm{WLA}=5,053$

Berdasarkan hasil perhitungan dengan memperhatikan beban kerja, jumlah pemintaan yang akan datang, dan jumlah hari efektif bekerja maka tenaga yang butuhkan untuk enam bulan kedepan memiliki rata-rata sebesar 5,254 $\approx 6$ orang. Hal ini menunjukkan UKM Rissolia perlu melakukan penambahan karyawan sebanyak 3 orang, karena saat ini jumlah karyawan yang dimiliki hanya 3 orang.

\section{b. Analisis Kebutuhan Tenaga Kerja}

Analisis kebutuhan tenaga kerja (Work Force Analysis) merupakan penentu kebutuhan tenaga kerja dengan memperhitungkan jumlah tenaga kerja, tingkat absensi, dan tingkat perputaran tenaga kerja (turn over). Hal tersebut dilakukan agar tidak terjadinya kekurangan maupun kelebihan tenaga kerja untuk waktu yang akan mendatang sehingga memberikan dampak terhadap kegiatan produksi yang efesien dan efektif.

1. Tingkat Absensi

Tingkat absensi karyawan merupakan rekap kehadiran tenaga kerja yang dilihat dari persentase tingkat ketidakhadiran untuk menentukan kebutuhan karyawan yang ideal pada UKM Rissolia. Adapun rekap tingkat absensi UKM Rissolia ditunjukkan pada Tabel 13.

Tabel 13. Tingkat Absensi Karyawan UKM Rissolia

\begin{tabular}{|c|c|c|c|c|}
\hline Bulan & $\begin{array}{c}\text { Jumlah } \\
\text { Tenaga Kerja } \\
\text { (Orang) }\end{array}$ & $\begin{array}{c}\text { Jumlah } \\
\text { Hari Kerja } \\
\text { (Hari) } \\
\end{array}$ & $\begin{array}{c}\text { Jumlah } \\
\text { Tidak Hadir } \\
\text { (Hari) } \\
\end{array}$ & $\begin{array}{c}\text { Tidak Hadir } \\
(\%)\end{array}$ \\
\hline Oktober 20 & 3 & 27 & 6 & $7 \%$ \\
\hline November 20 & 3 & 25 & 6 & $7 \%$ \\
\hline Desember 20 & 3 & 26 & 7 & $8 \%$ \\
\hline Januari 21 & 3 & 24 & 4 & $5 \%$ \\
\hline Februari 21 & 3 & 24 & 6 & $8 \%$ \\
\hline \multirow[t]{2}{*}{ Maret 21} & 3 & 26 & 6 & $7 \%$ \\
\hline & \multicolumn{2}{|c|}{ Rata-Rata } & & $7 \%$ \\
\hline
\end{tabular}

Sumber : UKM Rissolia

Tingkat Absensi bulan Oktober 2020 dapat diperhitungkan dengan persamaan sebagai berikut:

Tingkat absen $=\frac{\text { Hari Kerja yang Hilang }}{\text { Hari Kerja Tersedia }} \times 100 \%$

Tingkat absen $=\frac{6}{27 \times 3+6} \times 100 \%$

Tingkat absen $=6,897 \approx 7 \%$

Sehingga tingkat absen pada UKM Rissolia dari bulan Oktober 2020 - Maret 2021 memiliki rata-rata sebesar $7 \%$.

\section{Perputaran Tenaga Kerja}

Tingkat perputaran kerja yang dimaksud adalah masuk dan keluarnya karyawan dalam masa penilitian. Namun dalam penelitian yang dilakukan pemilik UKM Rissolia tidak menghendaki adanya penambahan dan pengurangan karyawan di tiap bulannya sehingga turn over pada UKM Rissolia adalah 0. 
Setelah data tingkat absensi dan perputaran tenaga kerja telah di dapatkan maka dilakukan analisis dengan metode Work Force Analysis pada Tabel 14.

Tabel 14. Analisis Kebutuhan Tenaga Kerja (Work Force Analysis)

\begin{tabular}{clcccc}
\hline No & Bulan & WLA $($ Orang) & Tidak Hadir $(\%)$ & Turn Over & WFA (Orang) \\
\hline 1 & April 21 & 5,053 & $7 \%$ & 0 & 5,124 \\
2 & Mei 21 & 6,256 & $7 \%$ & 0 & 6,327 \\
3 & Juni 21 & 5,053 & $7 \%$ & 0 & 5,124 \\
4 & Juli 21 & 5,053 & $7 \%$ & 0 & 5,124 \\
5 & Agustus 21 & 5,053 & $7 \%$ & 0 & 5,124 \\
6 & September 21 & 5,053 & $7 \%$ & 0 & 5,124 \\
& \multicolumn{2}{r}{ Rata-Rata } & & & 5,307 \\
\hline
\end{tabular}

Persamaan yang dipergunakan dalam menentukan jumlah karyawan pada bulan April 2021 sebagai berikut:

WFA $=$ WLA $+\%$ Absensi $+\%$ LTO

$\mathrm{WFA}=5,053+0,07+0$

$\mathrm{WFA}=5,124$

Berdasarkan hasil perhitungan dengan memperhatikan tingkat kehadiran dan perputaran tenaga kerja untuk 6 bulan kedepan yaitu bulan April-September 2021 memiliki rata-rata sebesar $5,325 \approx 6$ orang. Dengan demikian untuk menciptakan keseimbangan antara beban kerja dengan ketersediaan karyawan maka UKM Rissolia dapat melakukan penambahan karyawan sebanyak 3 orang. Saat ini karyawan pada UKM Rissolia hanya terdiri atas 3 orang.

\section{c. Analisis Biaya Karyawan}

Berdasarkan dengan perhitungan yang telah didapatkan baik menggunakan metode work load analysis maupun dengan work force analysis didapatkan nilai yang masih dapat dilakukan peninjuan lebih lanjut untuk menentukan jumlah karyawan yang ideal dan ekonomis.

Adapun dalam peninjauan ini maka dibutuhkan data gaji karyawan dan upah lembuh pada UKM Rissolia yang ditunjukkan pada Tabel 15.

Tabel 15. Biaya Upah Kerja dan Upah Lembur Karyawan pada UKM Rissolia

\begin{tabular}{|c|c|c|}
\hline No & Keterangan & Nominal \\
\hline 1 & Upah Kerja Karyawan & Rp 100.000/hari \\
\hline 2 & Upah Lembur Karyawan & $\mathrm{Rp} \quad 7.500 / \mathrm{jam}$ \\
\hline
\end{tabular}

Dilihat dari nilai tersebut maka dapat dilakukan dua kemungkinan bahwa UKM Rissolia mampu memenuhi kebutuhan konsumen dengan 5 orang karyawan atau dengan 6 orang karyawan tentunya memperhatikan biaya yang ekonomis. Oleh sebab itu maka perlu dilakukan analisis biaya untuk menentukan karyawan yang ideal untuk UKM Rissolia. Perhitungan dilakukan sebagai berikut :

1. Perhitungan 5 orang karyawan

Waktu Tersedia $=$ Jumlah Karyawan $\mathrm{x}$ waktu kerja efektif $\mathrm{x}$ Hari kerja efektif

Waktu Tersedia $=5 \times \frac{8 \text { jam }}{\text { hari }} \times 151$ hari

Waktu Tersedia $=6.040$ jam

Waktu yang dibutuhkan = Jumlah permintaan $\mathrm{x}$ waktu proses produksi

Waktu dibutuhkan $=15.457 \mathrm{pcs} \times 4,08 \mathrm{pcs} /$ menit

Waktu dibutuhkan $=92.742$ pcs $\times 4,08$ pcs $/$ menit

Waktu dibutuhkan $=378.387,36 \approx 378.388$ menit $=6.306,46 \mathrm{jam} \approx 6.307 \mathrm{jam}$

Maka waktu tersedia lebih kecil atau kurang dari waktu yang dibutuhkan dan memiliki selisih sebesar 267 jam. Hal ini menandakan dengan jumlah karyawan 5 orang membutuhkan jam lembur sebanyak 267 jam. Selanjutnya menentukan biaya lembur dan total biaya yang harus dikeluarkan 6 bulan kedepan untuk upah karyawan sebagai berikut:

Upah Lembur $=$ jumlah jam lembur $\mathrm{x}$ upah lembur/hari 
Jurnal SEOI - Fakultas Teknik Universitas Sahid Jakarta

Vol 3 edisi 2 tahun 2021

Upah Lembur $=267$ jam $\times$ Rp 7.500/jam

Upah Lembur $=$ Rp 2.002.500

Total Biaya $=$ Gaji Karyawan/hari $\mathrm{x}$ jumlah karyawan $\mathrm{x}$ hari kerja efektif + upah lembur

Total Biaya $=(\operatorname{Rp} 100.000 \times 5$ karyawan $\times 151$ hari $)+\operatorname{Rp} 2.002 .500$

Total Biaya $=$ Rp 77.502.500

2. Perhitungan 6 orang karyawan

Waktu Tersedia $=$ Jumlah Karyawan $\mathrm{x}$ waktu kerja efektif $\mathrm{x}$ Hari kerja efektif

Waktu Tersedia $=6 \times \frac{8 \text { jam }}{\text { hari }} \times 151$ hari

Waktu Tersedia $=7.248$ jam

Waktu dibutuhkan $=$ Jumlah permintaan $\mathrm{x}$ waktu proses produksi Waktu dibutuhkan $=92.742 \mathrm{pcs} \times 4,08 \mathrm{pcs} /$ menit

Waktu dibutuhkan $=378.387,36 \approx 378.388$ menit $=6.306,46 \mathrm{jam} \approx 6.307 \mathrm{jam}$

Maka waktu tersedia melebih waktu yang dibutuhkan dan memiliki selisih sebesar 941

jam. Hal ini menandakan dengan jumlah karyawan 6 orang akan terdapat waktu idle atau menganggur sebesar 941 jam di jam kerja normal. Selanjutnya total biaya yang harus dikeluarkan 6 bulan kedepan perbulannya untuk upah karyawan sebagai berikut :

Total Biaya $=$ Gaji Karyawan/hari $\mathrm{x}$ jumlah karyawan $\mathrm{x}$ hari kerja efektif

Total Biaya $=\mathrm{Rp} 100.000 \times 6$ karyawan $\times 151$ hari

Total Biaya $=\operatorname{Rp} \operatorname{Rp} 90.600 .000$

Berdasarkan perhitungan yang dilakukan maka jumlah karyawan yang ideal untuk UKM Rissolia dengan budget yang lebih ekonomis dengan selisih sebesar Rp 13.097.500 adalah sebanyak 5 orang. Maka UKM Rissolia dapat melakukan penambahan karyawan sebanyak 2 orang untuk divisi produksi, karena saat ini karyawan di divisi tersebut pada UKM Rissolia terdiri atas 3 orang.

\section{Kesimpulan}

Berdasarkan hasil penelitian yang telah dilakukan, maka dapat ditarik kesimpulan sebagai berikut:

a. Berdasarkan data penjualan keseluruhan menu utama pada UKM Rissolia yang terdiri dari risol mayo daging asap, risol rogut ayam, pastel, arem-arem, soes, dan pie buah pada bulan Oktober 2020 - Maret 2021 diperoleh peramalan permintaan untuk bulan April - September 2021 dengan metode Simple Average adalah sebanyak 92.742 pcs dengan jumlah permintaan setiap bulannya adalah $15.457 \mathrm{pcs}$. Hasil peramalan ini memiliki nilai kesalahan peramalan sebesar 29\%, dimana hal ini menunjukan bahwa dengan menggunakan metode Simple Average kemungkinan akan terdapat selisih antara hasil peramalan permintaan dengan permintaan aktual sebesar $29 \%$.

b. UKM Rissolia memiliki rata-rata geometrik waktu siklus untuk tiap varian sebesar 3,104 menit per pcs dan rata-rata waktu baku geometrik untuk tiap varian sebesar 4,080 menit per pcs dengan rincian sebagai berikut:

1. Risol rogut ayam membutuhkan waktu proses produksi selama 341 menit untuk menghasilkan produk sebanyak 150 pcs sehingga memiliki waktu siklus $2,27 \mathrm{menit} / \mathrm{pcs}$ dan waktu baku 2,99 menit/pcs.

2. Risol Mayo Daging Asap membutuhkan waktu proses produksi selama 237 menit untuk menghasilkan produk sebanyak 125 pcs sehingga memiliki waktu siklus 1,89 menit/pcs dan waktu baku 2,49 menit/pcs.

3. Pastel membutuhkan waktu proses produksi selama 226 menit untuk menghasilkan produk sebanyak 60 pcs sehingga memiliki waktu siklus 3,77 menit dan waktu baku 4,95 menit/pcs.

4. Arem-arem membutuhkan waktu proses produksi selama 265 menit untuk menghasilkan produk sebanyak 50 pcs sehingga memiliki waktu siklus 5,30 menit/pcs dan waktu baku 6,97 menit/pcs. 
5. Kue Soes membutuhkan waktu proses produksi selama 189 menit untuk menghasilkan produk sebanyak 60 pcs sehingga memiliki waktu siklus 3,15 menit/pcs dan waktu baku $4,14 \mathrm{menit} / \mathrm{pcs}$.

6. Pie Buah membutuhkan waktu selama 132 menit untuk menghasilkan produk sebanyak 40 pcs sehingga memiliki waktu siklus 3,30 menit/pcs dan waktu baku 4,34 menit/pcs.

c. Hasil analisis beban kerja dengan menggunakan metode Work Load Analysis yang memperhatikan jumlah permintaan, waktu produksi, dan waktu kerja yang tersedia diperoleh hasil bahwa UKM Rissolia membutuhkan sebanyak 5,236 orang. Sedangkan hasil analisis kebutuhan tenaga kerja dengan menggunakan metode Work Force Analysis yang memperhitungkan historis tingkat absensi karyawan dan perputaran tenaga kerja menunjukan bahwa UKM Rissolia membutuhkan tenaga kerja sebanyak 5,307 orang. Berdasarkan analisis biaya tenaga kerja dengan memperhatikan kemungkinan jam lembur jika menggunakan 5 orang karyawan dan idle time jika menggunakan 6 orang karyawan, maka jumlah karyawan yang dibutuhkan oleh UKM Rissolia adalah sebanyak 5 orang dengan selisih biaya tenaga kerja selama 6 bulan sebesar Rp 13.097.500 dibandingkan jika UKM Rissolia menggunakan 6 orang karyawan.

\section{Daftar Pustaka}

Anggawisastra, R., Sutalaksana, I. Z, dan Tjakraatmadja, J. H. (2006). Teknik Perancangan Sistem Kerja, Bandung: ITB.

Chapman, S. N. (2006). The Fundamentals of Production Planning and Control. New Jersey: Pearson Education.

Haryono, S. (2015). Manajemen Produksi \& Operasi. Jakarta: PT. Intermedia Personalita Utama .

Montgomery, D. C., Jennings, C. L., \& Kulahci, M. (2015). Introduction to Time Series Analysis and Forecasting. Canada: John WIley and Sons Inc.

Martoyo, S. (2000). Manajemen Sumber Daya Manusia. Yogjakarta.

Priyono. (2008). Manajemen Sumber Daya Manusia . Surabaya: Zifatama Publisher.

Purnomo, H. (2003). Pengantar Teknik Industri. Yogyakarta: Graha Ilmu.

Rinawati dkk., (2012), Penentuan Waktu Standar dan Jumlah Tenaga Kerja Optimal pada Produksi Batik Cap, Jurnal Teknik Industri. Universitas Diponegoro, Vol. VII.

Widodo, T., Fardiansyah, I., \& Wiharta, T. (2020). Analisis Beban Kerja Untuk Mengetahui Jumlah Pekerja Optimal Karyawan Polishing 3 Dengan Menggunakan Metode Workload Analysis di PT Surya Toto Indonesia, Tbk. Journal Industrial Manufacturing, 5(2), 45-52. doi:10.31000/jim.v5i2.3042

Wignjosoebroto, S. (2000). Ergonomi, Studi Gerak dan Waktu : Teknik Analisis untuk Peningkatan Produktivitas Kerja. Surabaya: Guna Widya. 